\title{
JACEK ZDZIEBORSKI
}

Università Pontificia Salesiana, Rzym

\section{SYMPOZJUM NAUKOWE \\ WEB 2.0 EDUCAZIONE E COMUNICAZIONE 2012 \\ (Rzym, 20-21 kwietnia 2012 r.)}

Wydział Nauk o Wychowaniu i czasopismo Orientamenti Pedagogi$c i$ we współpracy z Wydziałem Filozofii oraz Wydziałem Komunikacji Społecznej Università Pontificia Salesiana (Papieskiego Uniwersytetu Salezjańskiego) w Rzymie zorganizowały sympozjum na temat Web 2.0 educazione e comunicazione 2012 (Web 2.0 - edukacja i komunikacja 2012), które odbyło się w Rzymie w dniach 20-21 kwietnia 2012 roku. W pierwszym rzędzie było ono adresowane do studentów i pracowników naukowych uniwersytetu, jednak dzięki inspirującemu tematowi oraz szeroko rozpowszechnionym reklamom głównie w internecie (strony internetowe ww. fakultetów oraz specjalny profil na Facebooku), które dawały możliwość zapoznania się z tematyką szczegółową, spotkało się z zainteresowaniem wielu osób, co też przełożyło się na wysoką frekwencję. Zapisy były nieodpłatne, ale ze względów organizacyjnych obowiązkowe; w tym celu pomocą służyła udostępniona aplikacja online. Uczestnicy przybyli głównie z terenu Włoch (od miast położonych na północy po samo południe), jak również z zagranicy. Oprócz teczki z materiałami informacyjnymi każdy z uczestników otrzymał własny login i hasło do sieci wi-fi uniwersytetu w celu umożliwienia uczestnictwa w sposób bardziej interaktywny, co zresztą zakłada pojęcie web 2.0.

Czym jest web 2.0? Słowo „web” pochodzi z języka angielskiego i oznacza pajęczynę, która jest dobrym odzwierciedleniem nielinear- 
nego zapisu informacji, jakim jest internet. Strony internetowe, które wyświetlamy na ekranach za pomocą przeglądarek internetowych, są częścią jednej wielkiej sieci internetowej i są nazywane stronami web. Oznaczenie "2.0" w nazwie sugeruje, że powinno istnieć także web 1.0 i tak rzeczywiście jest. Internet był na początku wykorzystywany głównie w celu pozyskiwania informacji zapisanych w formie tekstów pisanych, obrazów, dźwięków, filmów, a zatem niewiele różnił się od telewizji, gdzie były jasno określone i rozdzielone osoby nadawcy i odbiorcy. A zatem web 1.0 ma charakter transmisji informacji w sposób jednokierunkowy: od autora do czytelnika.

Web 2.0, dzięki rozwojowi technologii komputerowych, uzyskał nowy charakter, bardziej społeczny i kolaboracyjny. W systemie 2.0 informacja nie jest już transmitowana $\mathrm{w}$ jednym kierunku, ale w obydwu, co oznacza, że także użytkownik Internetu, do tej pory bierny, może stać się autorem treści udostępnianych innym użytkownikom. Przykładem mogą być portale takie jak: Wikipedia, Facebook, Youtube i wiele innych, gdzie każdy może $\mathrm{w}$ jakimś stopniu wprowadzać i modyfikować dane. Wiele innych stron internetowych, działających do tej pory w wersji 1.0, udostępniło użytkownikom możliwość interakcji z autorem poprzez możliwość dodawania komentarzy, udziału w forum czy też czacie. Główną cechą web 2.0 zdaje się być zatem możliwość dzielenia się w sieci.

Przy tej okazji należy wspomnieć, że obecnie istnieje już trzecia kategoria web: web 3.0, która promuje wykorzystanie nowoczesnych technologii w Internecie, obecność tzw. sztucznej inteligencji, z której korzystamy chociażby w serwisie Google (tzw. dynamiczne wyszukiwanie), możliwość korzystania z najprzeróżniejszych aplikacji bezpośrednio na stronach internetowych, jak również możliwość wizualizacji materiałów stron internetowych za pomocą innych aplikacji komputerowych niż przeglądarki internetowe.

Powyższy opis różnic pomiędzy web 1.0, web 2.0 a web 3.0 nie jest wyczerpujący; został przedstawiony w dużym skrócie w celu ułatwienia zrozumienia, o czym była mowa na sympozjum. Wartym zauważenia jest fakt, że w dobie tak szybko rozwijających się technologii interneto- 
wych, z których z dość dużym powodzeniem korzystają najmłodsi użytkownicy internetu, należy zweryfikować obecne sposoby komunikowania i nauczania, i tym tematom były poświęcone konferencje.

Pierwszego dnia sympozjum (piątek, 21 kwietnia, godz. 14.00-20.00) odbyły się cztery konferencje. Jako pierwszy wystąił prof. Sergio Rondinara z wykładem pt. „Filozofia i web 2.0”. Jako drugi miał wystapić prof. Pier Cesare Rivoltella z tematem „Edukacja i web 2.0”, lecz niestety nie dojechał. Ostatecznie wykład na ten temat wygłosił prof. Cristian Desbouts SDB, organizator sympozjum. Po powyższych dwóch konferencjach i przerwie na kawę odbyły się kolejne dwie prelekcje. Najpierw prof. Fabio Pasqualetti SDB mówił na temat „Komunikacja i web 2.0”, a po nim prof. Ricardo Orzona z Argentyny - na temat „Duszpasterstwo i web 2.0". Na zakończenie pierwszego dnia sympozjum miała miejsce dyskusja prelegentów z publicznością.

Spotkania drugiego dnia były podzielone na dwie części: teoretyczną i praktyczną. Część pierwsza, mająca miejsce w godzinach przedpołudniowych, pozwalała na uczestnictwo w konferencji przygotowanej przez prof. Martina Leonidasa z Hiszpanii na temat: „Ruchy społeczne i web 2.0" oraz w drugiej konferencji: „Neuronauka i web 2.0” przeprowadzonej przez prof. Dario Catania. Po przerwie sesji przedpołudniowej miał być jeszcze wykład ks. prof. Desboutsa na temat: „Tożsamość, samoocena i web 2.0", ale z powodu nieobecności prof. Rivoltelli na sympozjum, prof. Debouts miał swoje wystapienie pierwszego dnia na przedstawiony wcześniej temat. W jego miejsce natomiast została przygotowana prezentacja nowego słownika komunikacji społecznej ( $\mathrm{La}$ Comunicazione: il dizionario di scienze e tecniche $)^{1}$, przygotowanego w wersji online. Prezentacji dokonał prof. Franco Lever SDB.

Po obiedzie, podczas sesji popołudniowej, miały miejsce warsztaty tematyczne. Ponieważ odbywały się w tym samym czasie, przy zapisie należało określić swoją preferencję i zapisać się na jeden z następujących:

${ }^{1}$ Słownik jest dostępny na stronie: http://www.lacomunicazione.it (otwarty 20.11.2012). 
a) Google Educator (Laura Boncini)

b) iPad i iPhone jako narzędzia dydaktyczne (Domizio Baldini)

c) Web i edukacja (Young for Young)

d) Hipertekst (Igino Domanin)

e) Dziennikarstwo i web 2.0 (Roberto Cotroneo)

f) Życie parafialne, katecheza $i$ web 2.0 (Hugo Torres)

g) Badania naukowe $i$ web 2.0 (Anthony Lobo).

Warsztaty trwały od godz. 14.30 do 17.30 , po czym był czas na ostatnie spotkanie plenarne w celu dyskusji, podsumowania, zakończenia oraz wręczenia certyfikatów uczestnictwa. Program sympozjum, jak i nagrania wystapień prelegentów, zostały udostępnione na specjalnie przygotowanej stronie internetowej ${ }^{2}$. Ponadto wszystkie wygłoszone konferencje ukazały się w formie artykułów w ostatnim numerze „Orientamenti Pedagogici” z 2012 r., które to wydanie zostało rozesłane do wszystkich uczestników. Pomocą służyły również przygotowane dwa stoiska $\mathrm{w}$ holu uniwersytetu; jedno $\mathrm{z}$ książkami o tematyce powiązanej z tematem sympozjum przygotowane przez księgarnię uniwersytecka, drugie ze sprzętem firmy Apple przygotowane przez rzymskiego sprzedawcę tychże produktów, „Flaminia Computer”.

Web 2.0 jest wielkim osiagnięciem technologicznym, ale stanowi jednocześnie wyzwanie, m.in. dla edukacji. Web 2.0 kształtuje nowy rodzaj społeczeństwa, tzw. społeczeństwo cyfrowe, którego szczególnymi reprezentantami są Digital Natives. Wiele ruchów społecznych rozwija się dzięki możliwościom internetu. Ponadto długie godziny poświęcone na nawigowanie $\mathrm{w}$ internecie $\mathrm{i}$ gry komputerowe powodują nawet zmiany w mózgu 3 . „Osoby web 2.0” inaczej myślą, uczą się, pracują, jak również inaczej kształtują nowe relacje. Technologie web 2.0 stają się mediatorem w kontaktach międzyosobowych oraz umożliwiają wspólną

\footnotetext{
${ }^{2}$ Strona internetowa sympozjum jest dostępna pod adresem: http://fse2.unisal.it/ op/convegno2012/index.html (otwarty 20.11.2012).

${ }^{3}$ Zob. G. Small i G. Vorgan, iBrain: Surviving the Technological Alteration of the Modern Mind, New York, HarperCollins Publishers, 2008. Książka została przetłumaczona na język polski pod tytułem iMózg i wydana w 2011 r. przez wydawnictwo Vesper.
} 
pracę na odległość. Dzięki nowym technologiom jest możliwa na przykład praca nad jednym tekstem bez konieczności przebywania razem w sposób fizyczny. Oczywiście to niesie ze sobą również zagrożenia; przykładem jest wspomniana wcześniej Wikipedia - encyklopedia internetowa tworzona przez użytkowników, gdzie każdy może dodawać i modyfikować zawartość haseł w sposób mniej lub bardziej odpowiedzialny. Internet w wydaniu 2.0 daje użytkownikom dużo więcej swobody, ale wymaga współpracy. Ważne jest, aby pamiętać, że osiagnięcia technologiczne nie zastąpią nauczyciela, lecz są dla niego pomocą. Alfabetyzacja cyfrowa to ciagle sprawa myślenia, a nie samych narzędzi. 